\title{
Curtipleon heterochelatum, a New Species of Tanaidacea (Crustacea: Peracarida) from the Andaman Sea
}

\author{
Kim Larsen \\ Department of Marine Invertebrates, Zoological Museum, University of Copenhagen, \\ Universitetsparken 15, 2100 Copenhagen Ø, Denmark \\ Present address: Department of Oceanography, Texas A \& $M$ University 3146, \\ College Station, Texas 77843-3146, USA \\ E-mail: tanaids@hotmail.com
}

(Received 13 November 2000; Accepted 4 February 2002)

\begin{abstract}
A new tanaidacean species of the family Metapseudidae, Curtipleon heterochelatum, is described and illustrated on the basis of one male and five female specimens from the Andaman Sea. A significant asymmetry in the male chelipeds was observed. The new species can be separated from $C$. carinatoides (Bãcescu, 1976) by the absence of spines on the anterior margin of the cephalothorax, and from C. carinatum (Makkaveeva, 1971) by the many spines on the cheliped basis and the distally directed subdistal spine on the dorsal surface of the male cheliped carpus. A revised diagnosis to Curtipleon and a key to the species of the genus are included.
\end{abstract}

Key Words: Crustacea, Peracarida, Tanaidacea, Curtipleon, new species, taxonomy, Andaman Sea.

\section{Introduction}

During the International Workshop on the Biodiversity of Crustaceans in the Andaman Sea, held at Phuket, Thailand in 1998 (BIOSHELF Program), extensive material of Tanaidacea was collected from shallow waters around Phuket. Subsequent examination of the material has revealed a number of undescribed species. Recently two new species from this material has been described (Larsen and Rayment 2002). In this paper, a new species of the genus Curtipleon Bãcescu, 1976, Curtipleon heterochelatum, is described based on six specimens.

The genus Curtipleon was erected by Bãcescu (1976b) to accommodate Synapseudes carinatus Makkaveeva, 1971 from the Red Sea and S. carinatoides Bãcescu, 1976 in 1976a from Tanzanian waters, both of which are little-known species that inhabit crevices in corals or coral rubble. An amended diagnosis of the genus is provided, as the generic diagnosis given by Bãcescu (1976b) is insufficient. The most striking features of the genus are the fused pleon/pleotelson and the uniramous uropods, both unique characters within the suborder Apseudomorpha. A key to the three species of the genus is given. 


\section{Materials and Methods}

Coral rubble was collected by the author on 5 December 1998 by scuba diving off Racha Yai Island, Andaman Sea coast of Thailand, at depths of 18-26 m. The collected rubble was washed thoroughly in fresh water to release attached fauna. The washings were then transferred back to seawater and sorted live during the workshop. Tanaidaceans where preserved in $10 \%$ formalin and transferred to $80 \%$ alcohol after 24 hours. Illustrations of whole animals and dissected mouthparts mounted in glycerine jelly were prepared by using a Camera Lucida attached to a Leitz Laborlux 12 compound scope with Leitz optics. Description of the female body of the new species is based on the holotype and the description of the male body is based on a male paratype. Appendages were dissected from the female paratype. The morphological terminology follows that employed by Dojiri and Sieg (1997) and Larsen and Rayment (2002). The type specimens of the new species are deposited in the Phuket Marine Biological Center, Phuket, Thailand (PMBC) and Zoological Museum, University of Copenhagen, Denmark (ZMUC). The abbreviation bl indicates total body length. For comparative purpose, the male holotype of Curtipleon carinatoides (Gr. Antipa Museum No. 305; bl $3.4 \mathrm{~mm}$ ) was also examined.

\section{Taxonomy \\ Family Metapseudidae \\ Subfamily Synapseudinae \\ Genus Curtipleon Bãcescu, 1976}

Synapseudes: Makkaveeva 1971: 93, fig. 31A-H (part).

Curtipleon Bãcescu, 1976b: 51, figs 1A, B, 53.

Type species. Synapseudes carinatoides Bãcescu, 1976 in 1976a.

Gender. Neuter.

Amended diagnosis (modified from Bãcescu 1976b). Ocular lobes with visual elements. Many spines and prominent projections prsent on dorsal surface of body. Pleon fused with pleotelson. Antennae and pereopods with conspicuous spinearmament. Maxilliped endites inconspicuous. Chelipeds greatly asymmetrical in males. Pleopods absent in both sexes. Uropods small, bent upward, uniramous.

Remarks. The original diagnosis by Bãcescu (1976b) consisted of only 4 characters due to the small number of species and the uncertainty of whether the characters were specific or generic. With the finding of the new species a number of specific characters can be elevated to generic rank. The genus is currently represented by only three species: $C$. carinatoides, $C$. carinatum, and $C$. heterochelatum.

\section{Curtipleon heterochelatum sp. nov.} (Figs 1-4)

Material examined. Holotype: ovigerous female (PMBC 15380), bl $2.95 \mathrm{~mm}$. Paratypes: 1 male (PMBC 15381), bl $3.0 \mathrm{~mm}$; 2 non-ovigerous females (PMBC 15816, 

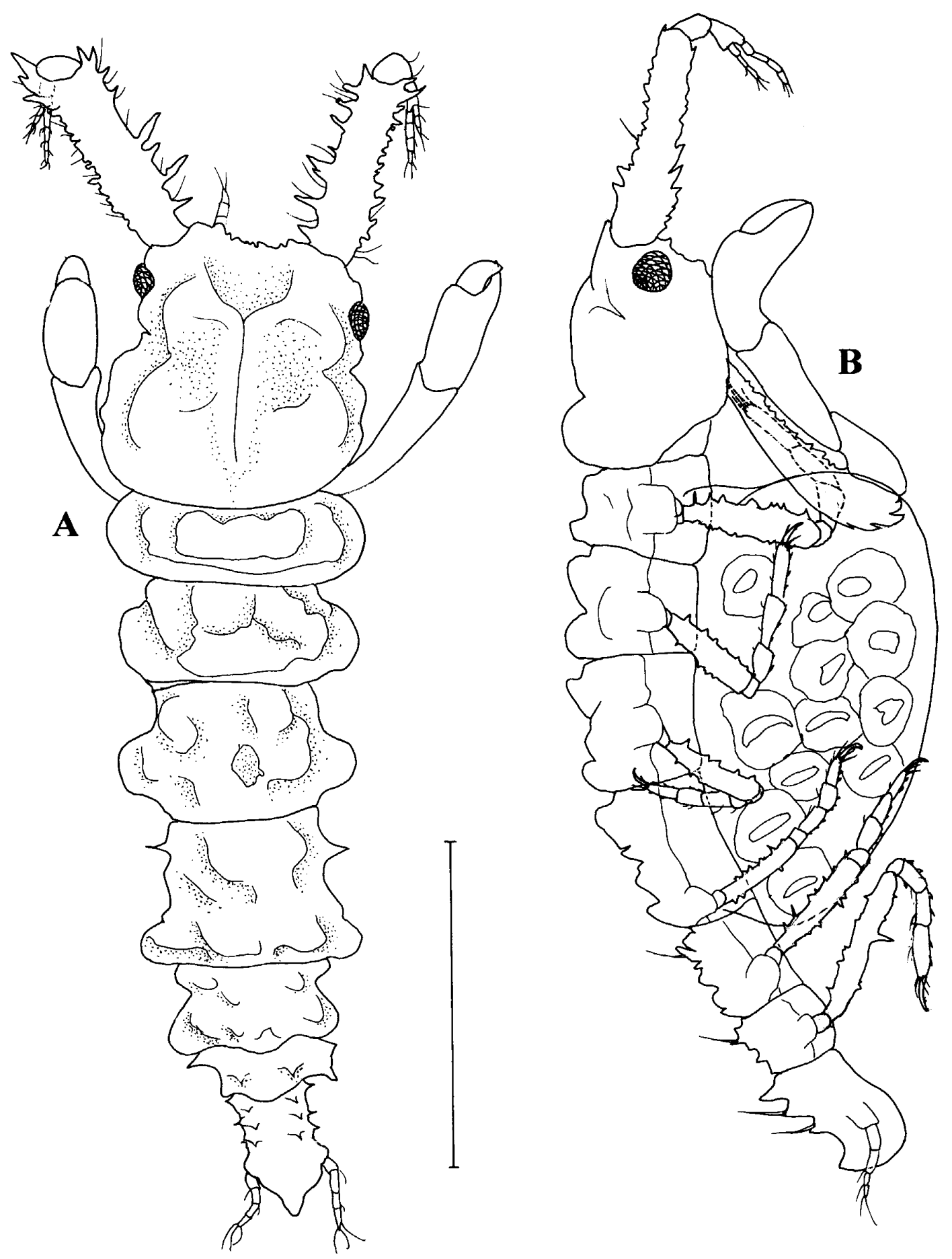

Fig. 1. Curtipleon heterochelatum sp. nov., female holotype (PMBC 15380). A, dorsal view; B, lateral view. Scale bar $=1 \mathrm{~mm}$.

bl $2.8 \mathrm{~mm}$ and ZMUC CRU-3661, bl $2.75 \mathrm{~mm}$ ), mouthparts and limbs dissected from one of them. Other material: 1 non-ovigerous female (SEM stub, bl $2.6 \mathrm{~mm}$ ) and 1 damaged non-ovigerous female, bl $2.7 \mathrm{~mm}$.

Diagnosis. Anterior margin of cephalothorax concave, without rostrum but 
with numerous tubercles. Cheliped with bluntly pointed fixed finger, lacking terminal spine. Male left cheliped about twice as large as right one.

Description. Female (Figs 1-3). Body (Fig. 1A, B) dorso-ventrally flattened, with several large projections.

Cephalothorax longer than pereonites 1 and 2 combined, with Y-shaped dorsal ridge and lateral depressions at midlength; anterior margin concave without spines but with many blunt tubercles; rostrum absent. Ocular lobes well developed with visual elements.

Pereonites without ventral hyposphenians. Pereonite 10.8 times as long as pereonite 2. Pereonite 31.25 times as long as pereonite 2. Pereonite 4 longer than other pereonites. Pereonite 51.3 times as long as pereonite 6 , narrower than pereonites 1-4. Pereonite 6 narrower and shorter than other pereonites.

Pleonites all fused with pleotelson; combined length of all pleonites and pleotelson shorter than that of pereonite 4 .

Antennule (Fig. 2A) longer than carapace. Peduncular article 1 longer than all succeeding articles and flagellum combined, with numerous small to large spines and setae. Peduncular article 2 globular, with prominent, anteriorly directed spine. Peduncular article 3 without spine. Inner flagellum with 3 articles; all articles with distal setae. Outer flagellum longer than inner flagellum, composed of 4 articles all bearing distal setae. Antenna (Fig. 2B) less than half as long as antennule peduncular aricle 1 . Peduncle broken. Inner flagellum reduced to small process on article 2 (not illustrated). Outer flagellum composed of 5 articles; article 1 twice as wide as other articles, with ventral serration.

Mandibles (Fig. 2C, D) each with narrow molar process longer than incisor. Palp with 3 articles; distal 2 articles each with setae. Left mandible with lacina mobilis lacking denticles; incisor with 2 denticles; setal row consisting of 3 bi- or trifurcate setae. Right mandible incisor without denticles; setal row consisting of 3 bifurcate and 14-denticulate setae. Maxillule (Fig. 2F) with palp consisting of 2 articles; distal article with 4 simple setae. Outer endite with 6 simple or bifurcate setae. Inner endite with 5 simple or bifurcate setae. Maxilla (Fig. 2G) with outer lobe of fixed endite bearing few simple setae and dense row of rigid, distally curved setae. Inner lobe of fixed endite with simple and distally serrated spiniform setae. Inner and outer lobes of movable endite with simple setae. Labium (Fig. 2E) with basal part setulose on anterior margin; articles each with setae on apex.

Maxilliped (Fig. 2H) with coxa narrower than basis. Basis smooth. Endite small and narrow, with 2 small, spiniform setae. Palp composed of 4 articles; article 1 smooth; article 2 wider and longer than other articles, with dense row of setae on inner margin and distal denticles on both inner and outer margins; article 3 almost globular with inner row of thick setae; article 4 minute with 2 thick setae. Epignath (Fig. 2I) bearing fine setules on apex.

Cheliped (Fig. 2J) with coxa 0.5 times as wide as basis. Basis shorter than carpus, with several simple spines on dorsal margin and several hooked spines on ventral margin. Merus slightly curved, tapering distally, with 2 ventrodistal spines. Carpus elongate, longer than propodus, with distal setae on dorsal margin. Propodus with several ventral setae. Fixed finger slightly shorter than dactylus, with 5 ventral setae; inner margin with 4 setae, but without denticles or terminal spine. Dactylus half as wide as fixed finger, smooth.

Oostegites present on pereonites 1-4. 


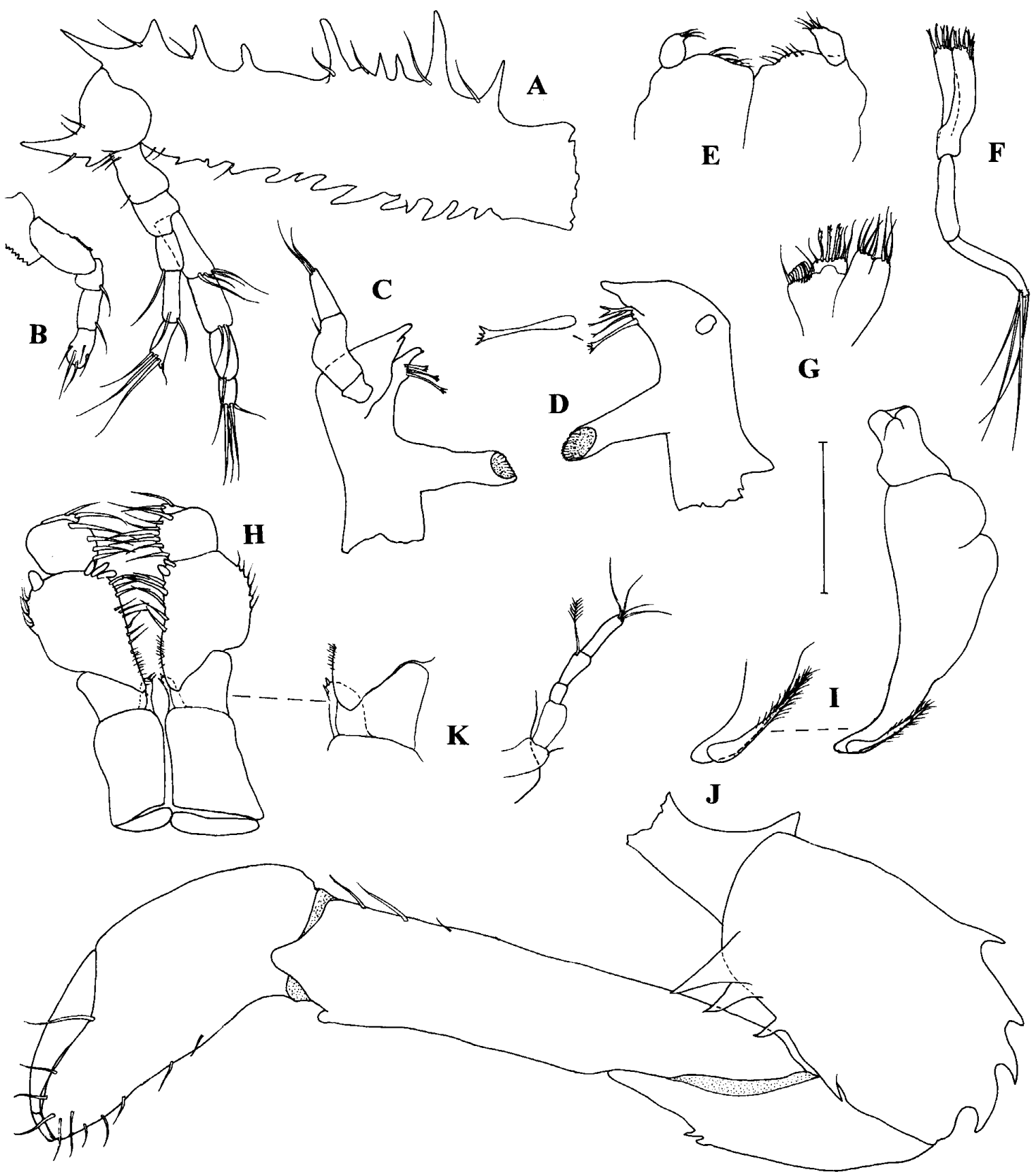

Fig. 2. Curtipleon heterochelatum sp. nov., appendages of female paratype (ZMUC CRU3661), mostly taken from the left side of the specimen. A, antennule; B, antenna; C, left mandible; D, right mandible (inset, detail of seta on incisor); E, labium; F, maxillule; G, maxilla; H, maxilliped; I, epignath; J, cheliped; K, uropod. Scale bar $=0.25 \mathrm{~mm}$.

Pereopod 1 (Fig. 3A) with small but distinct coxa. Basis longer than ischium, merus, and carpus combined, with 5 large, dorsal spines and numerous setae, especially on ventral margin. Ischium with 1 ventrodistal seta. Merus slightly shorter than carpus, with several simple setae and 1 spiniform seta on ventral margin. Carpus as long as propodus; ventral margin with several spiniform and 2 sensory 


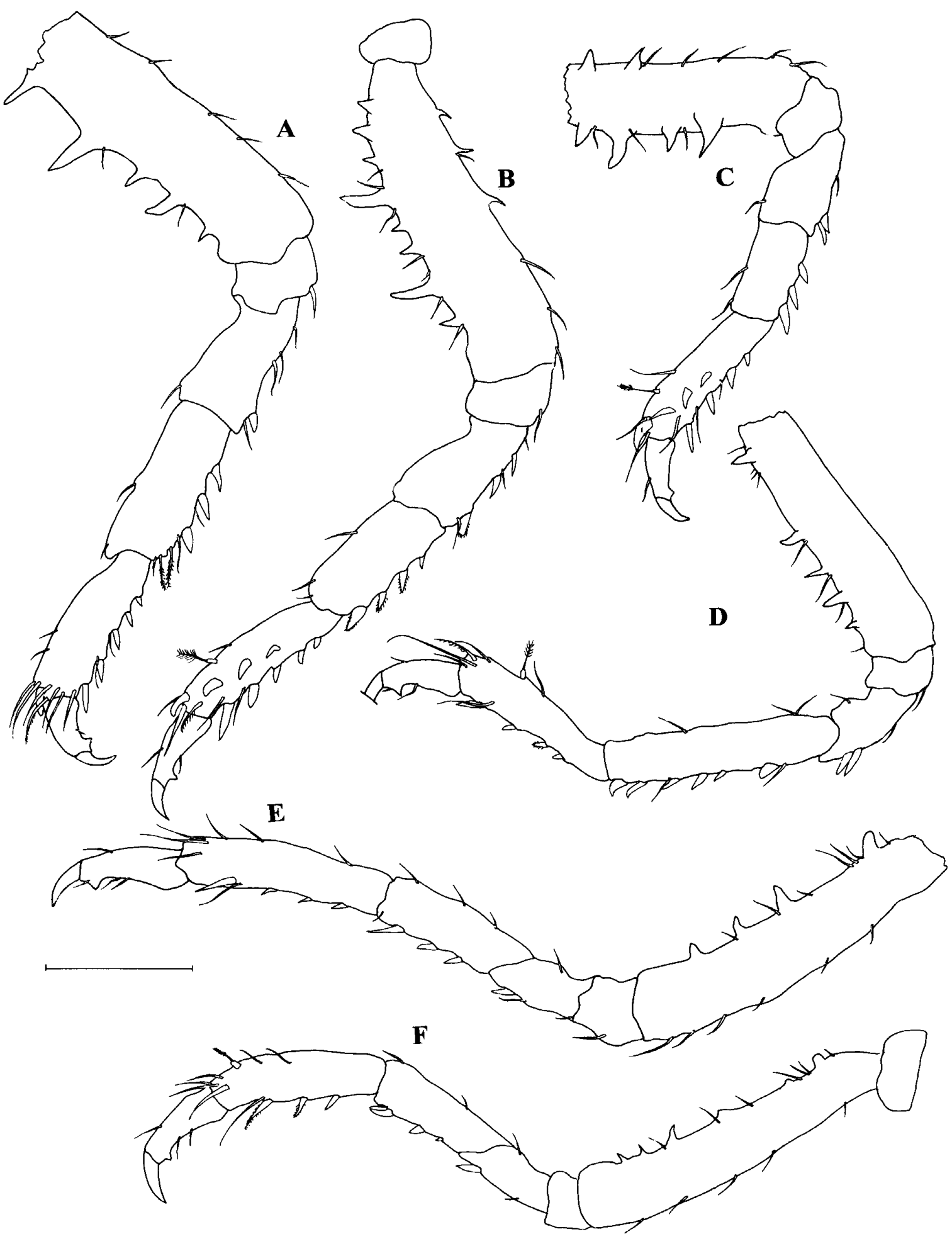

Fig. 3. Curtipleon heterochelatum sp. nov., left appendages of female paratype (ZMUC CRU3661). A, pereopod 1; B, pereopod 2; C, pereopod 3; D, pereopod 4; E, pereopod 5; F, pereopod 6. Scale bar $=0.25 \mathrm{~mm}$. 
setae; dorsal margin with only 2 simple setae. Propodus twice as long as dactylus, distally bearing numerous rigid setae and 1 spiniform seta; ventral margin with 5 spiniform setae and several simple setae. Dactylus longer than ischium, with simple setae and ventral spine proximal to base of corneous unguis. Pereopod 2 (Fig. 3B) similar to pereopod 1 except for basis bearing 8 dorsal spines and 3 ventral spines. Merus with 3 spiniform dorsal setae. Propodus longer than carpus, laterally bearing row of 3 spiniform setae. Pereopod 3 (Fig. 3C) similar to pereopod 2 except for merus bearing 2 spiniform setae. Carpus shorter than that of pereopod 1 , with 3 spiniform setae. Propodus armed ventrally with 4 spiniform setae and laterally with row of 3 spiniform setae. Pereopod 4 (Fig. 3D) with basis bearing 5 dorsal spines but lacking ventral spines. Ischium with 1 ventral seta. Merus short, only 0.3 times as long as carpus, ventrally with 2 spiniform setae. Carpus longer than propodus, with 6 ventral spiniform setae. Propodus with 4 spiniform ventral setae but without lateral spiniform seta. Pereopod 5 (Fig. 3E) similar to pereopod 4 except for merus bearing 1 spiniform seta. Carpus shorter than that of pereopod 4 and shorter than propodus. Pereopod 6 (Fig. 3 F) similar to pereopod 5 except for propodus bearing 3 spiniform setae.

Uropods (Fig. 2K) uniramous. Protopod smooth. Endopod with 3 articles; article 2 with 1 sensory seta and article 3 with 4 simple setae.

Male (Fig. 4A, B). Body segments slightly narrower than those of female in dorsal view. Pereonite 1 proportionally longer than that of female. Pereonites 3-6 proportionally shorter than those of female.

Chelipeds strongly asymmetrical. Left cheliped with basis 3 times wider than that of right cheliped, and left propodus more than 2.5 times wider than that of right cheliped. Carpi of both chelipeds armed dorsally with anteriorly directed subdistal spine. Spines on basis much less acute than in female. Right cheliped with fixed finger and dactylus almost smooth, while those of left cheliped with 2 projections each.

Etymology. The species is named after the asymmetry of the male chelipeds (Latin, adjective: hetero-chelatum = of different-cheliped).

Remarks. In order to ascertain specific differences between Curtipleon heterochelatum and $C$. carinatoides, the present specimens and the holotype male of $C$. carinatoides were compared. The numerous paratypes, including female specimens (Gr. Antipa Museum No 306), could not be found and are presumed lost (I. Petrescu, pers. comm.). Curtipleon heterochelatum is immediately distinguished from $C$. carinatoides by the absence of prominent spines on the anterior margin of the cephalothorax. In $C$. carinatoides the anterior margin is armed with prominent spines medially and near the base of the antennules.

Makkaveeva's (1971) original description of $C$. carinatum is inadequate for detailed comparison, and neither type nor supplemental material of the species has been available for study. Nevertheless, the new species is different from $C$. carinatum as originally described in the following respects: the cheliped basis bears several spines on the anterior and posterior margins in $C$. heterochelatum, while it is unarmed in $C$. carinatum; the carpus of the male cheliped bears a subdistal spine on the dorsal margin in $C$. heterochelatum, while it is unarmed in $C$. carinatum. The descriptive text and illustrations of the pleotelson are not consistent in the original description of $C$. carinatum by Makkaveeva (1971). A rounded terminal margin of the pleotelson is illustrated, but the text describes the mentioned margin 


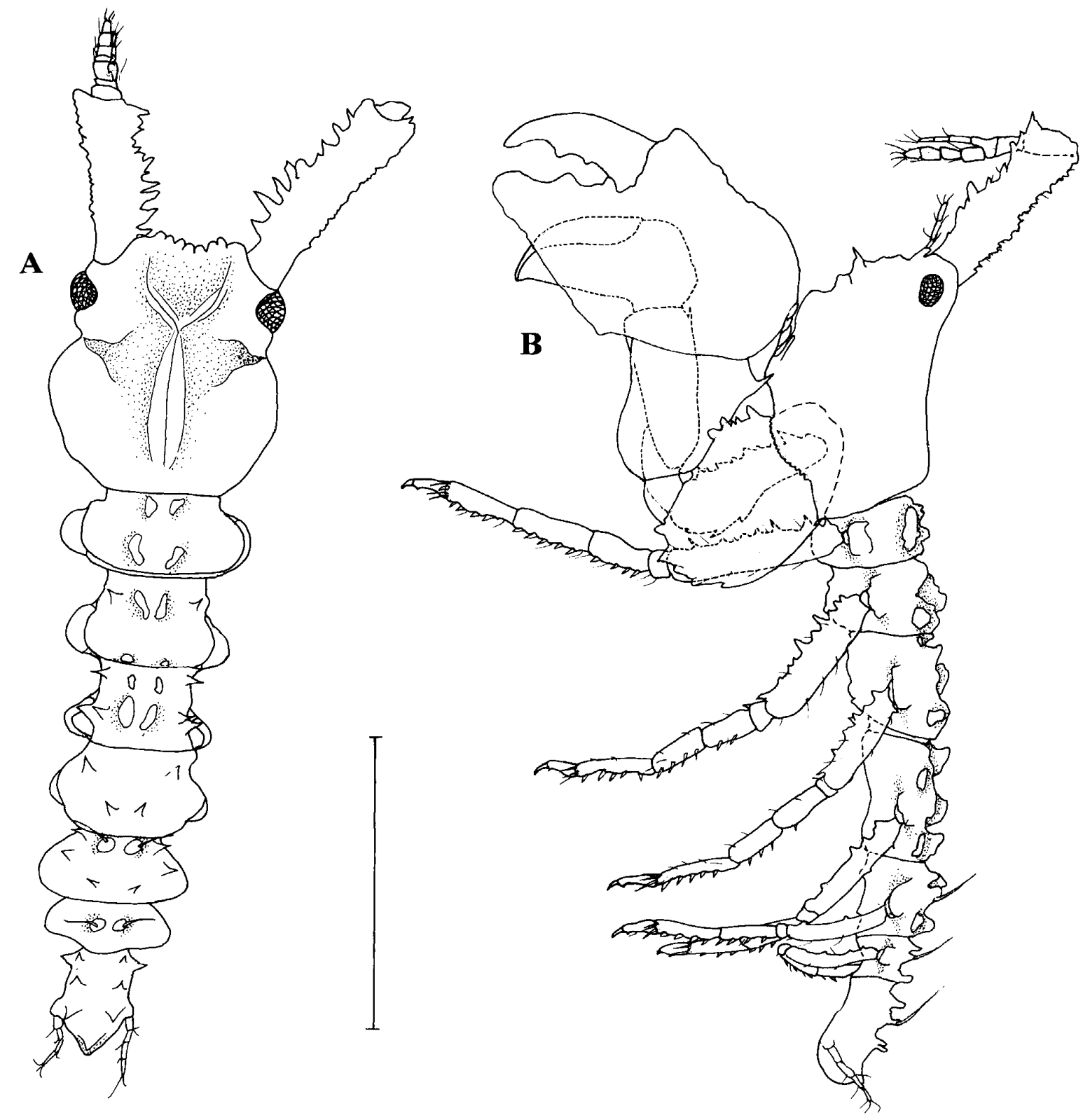

Fig. 4. Curtipleon heterochelatum sp. nov., male paratype (PMBC 15381). A, dorsal view; B, lateral view. Scale bar $=1 \mathrm{~mm}$.

as triangular (i.e. three-pointed). Furthermore, the illustration of Makkaveeva shows the mandibular molar process to be reduced. This must be construed as an artistic error, because reduction of the mandibular molar has never been reported in the Apseudomorpha by any other worker.

Asymmetry of the chelipeds has been reported in various taxa of Tanaidacea. It has been attributed to regeneration in Synapseudes (Shiino 1951) and Neotanais (Larsen 1999) or to abnormality in the case of Leptochelia (Kazmi and Siddiqui 1992). Asymmetrical chelipeds have also been observed in males of Pagurapseudes (Bãcescu 1976c) and Macrolabrum (Gutu 1997). These authors considered the asymmetry to be an adaptation to the specialised life strategy of occupying mollusc 
shells, but both fail to explain why females do not display similar asymmetry. Bãcescu (1976a) also reported asymmetrical male chelipeds in Indoapseudes but did not comment further. The extent of the asymmetry and the structure of the male chelipeds in Curtipleon cannot be considered to be the results of regrowth following loss of the right cheliped. The specimens were found to live freely among coral rubble, so the asymmetry cannot be an adaptation for shell dwelling. Perhaps in $C$. heterochelatum the asymmetry is a reproductive adaptation, possibly for attracting females as in the brachyuran Uca, or may be related to male fighting behaviour, which is known in other tanaidaceans (Highsmith 1983), although these do not have asymmetrical chelipeds.

\section{Key to the Species of Curtipleon}

1. Anterior margin of cephalothorax with prominent median and lateral spines C. carinatoides

- Anterior margin of cephalothorax with several blunt tubercles, but without spines

2. Cheliped basis with numerous spines and male cheliped carpus with anteriorly directed distal spine.... C. heterochelatum sp. nov.

- Cheliped basis lacking spines and male cheliped carpus without anteriorly directed distal spine C. carinatum

\section{Acknowledgements}

Financial support for participation in the International Workshop on the Biodiversity of Crustaceans in the Andaman Sea was provided by DANIDA (Danish International Development Assistance). Thanks are extended to Dr. Matz Berggren, Dr. Niel L. Bruce, and PMBC staff for organising the workshop. I thank Prof. E. G. Otvos for translating the Russian text of Makkaveeva and also extend my thanks to Dr. M. E. Petersen and Mr. J. McLelland for correcting the language. Finally, I thank the reviewers for greatly improving the manuscript and particularly the associate editor for his patience and much advice. The BIOSHELF program provided the material used in this publication.

\section{References}

Bãcescu, M. 1976a. Three new genera and six new species of Monokonophora (Crustacea, Tanaidacea) from the coral reefs of Tanzania. University Science Journal (Dar es Salaam) 2(1): 3-24.

Bãcescu, M. 1976b. Representatives of the family Synapseudidae (Crustacea, Tanaidacea) from the Tanzanian coral reefs: one new genus (Curtipleon) and three new species of Synapseudes. Travaux du Muséum d'Histoire Naturelle Grigore Antipa 17: 51-63.

Bãcescu, M. 1976c. Contribution to the knowledge of the family Pagurapseudidae (CrustaceaTanaidacea) occurring in the infralittoral area of the west Indian Ocean (Tanzanian Waters). Revue Roumaine de Biologie (Biologie Animale) 21: 3-11. 
Dojiri, M. and Sieg, J. 1997. The Tanaidacea. Pp. 181-278. In: Blake, J. A. and Scott, P. H. (Eds) Taxonomic Atlas of the Benthic Fauna of the Santa Maria Basin and Western Santa Barbara Channel. 11- the Crustacea. Part 2 The Isopoda, Cumacea and Tanaidacea. I-V. Santa Barbara Museum of Natural History, Santa Barbara, $270 \mathrm{pp}$.

Gutu, M. 1997. Tanaidacea. In: Gutu, M. (Co-ordinator), Results of the Zoological Expedition organized by «Grigore Antipa $\gg$ Museum in the Indonesian Archipelago (1991). I. Peracarida (Crustacea). Travaux du Muséum d'Histoire Naturelle Grigore Antipa 38: 259-327.

Highsmith, R. C. 1983. Sex reversal and fighting behaviour: coevolved phenomena in a tanaid crustacean. Ecology 64: 719-726.

Kazmi, Q. B. and Siddiqui, F. A. 1992. Note on an anomalous tanaid: Leptochelia sp. (Crustacea, Tanaidacea) collected from Manora Channel (Northern Arabian Sea). Pakistan Journal of Marine Sciences 1: 65-67.

Larsen, K. 1999. Deep-sea tanaidaceans (Crustacea: Peracarida) from the Albatross cruises 1885-86, with keys to the suborder Neotanaidomorpha. Journal of Natural History 33: $1107-1132$.

Larsen, K. and Rayment, H. 2002. New species of Leptochelia (Crustacea: Tanaidacea) from the Andaman Sea, North-eastern Indian Ocean. Phuket Marine Biological Center, Special Publication 22: 1-14.

Makkaveeva, E. B. 1971. Kachestvenniy sostav i kolichestvennoe raspredelinie tanaidovikh rakov $\mathrm{v}$ Krasnom More [Qualitative composition and quantitative distribution of tanaidacean crustaceans in the Red Sea]. Pp. 88-108. In: Anonymus (Ed.) Bentos Shelfa Krasnogo Morya [Shelf Benthos of the Red Sea]. Naukova Dumka, Kiev, 211 pp.

Shiino, S. M. 1951. On two new species of the family Apseudidae found at Seto. Report of Faculty of Fisheries, Prefectural University of Mie 1: 11-25. 